\title{
WILLINGNESS TO DONATE AND PREFERENCES OF ZOOS/SAFARI PARKS VISITORS TOWARD ENDANGERED MAMMALS CONSERVATION
}

\author{
ARZYANA SUNKAR ${ }^{1 *}$, Eva RACHMAWATI ${ }^{1)}$, YANTO SANTOSA $^{1)}$, AND SiTI HASANAH ${ }^{2)}$ \\ 1) Department of Forest Resources Conservation and Ecotourism, Faculty of Forestry and Environment, IPB \\ University,Bogor, 16680, Indonesia \\ ${ }^{2)}$ Sekolah Alam Rimba, Bogor, 16154, Indonesia \\ *Email: arzyanas@gmail.com
}

Accepted August 04, 2021 / Approved October 21, 2021

\begin{abstract}
A person may contribute to the conservation of species through donations. The willingness to donate (WTD) to conserve endangered species can depend on many factors. This research aims to determine the willingness of visitors to Indonesia's zoos and safari parks to make a donation for species conservation and identify the determinants of their WTD through preferences toward certain species. This research focused on 12 priority endangered mammals. The study began with a preliminary survey of 110 respondents in January 2020, followed by data collection in February 2020 involving 1011 adult visitors to zoos and safari parks in Java and Bali. Specifically, descriptive statistics in the form of percentages ere used to analyze the influence of preferences toward species conservation and amount of donation while considering individual characteristics such as gender, age, place of residence, occupation, and level of education. Our results confirmed that mammals, mega-herbivores and large carnivores are very popular among young adult visitors. Overall, the results demonstrated that visitors placed rhino, elephant and tiger as the three priority species to be conserved in terms of donation given. It is clear that these three charismatic species have a very high conservation value in the eyes of the people. Furthermore, the characteristics of species and the knowledge and psychological preferences of the visitors can contribute to the determination of the preference for the number of donations to certain wildlife species.
\end{abstract}

Key words: charismatic species, conservation institutions, demographic characteristics, Indonesia, primate

\section{INTRODUCTION}

One of the easiest locations for wildlife viewing and to observe wildlife preferences is in zoos, where a variety of wildlife is placed in one location. The Minister of Forestry Regulation Number P.51/Menhut-II/2012 on Conservation Institutions, defines a zoo as the place of conservation of a minimum of three (3) taxa, limited in an area of at least 15 (fifteen) hectares, in which visitors can observe without using motorised vehicles (motorcycles or cars). In addition to the zoo, the safari park is also one of the other locations where humans and wildlife come into contact. The zoo and safari park are both designated as conservation institutions (Minister of Forestry Regulation Number P.51/Menhut-II/2012). They are involved in wildlife conservation activities outside their natural habitat (ex-situ), in the form of government- and non-government- run institutions.

Visitors have preferences for specific wildlife species. These preferences are influenced by various variables such as the popularity of the species (which is driven by advertising the species in the media), physical attractivity, size and conservation status. There also appears to be a preference for the conservation of animals that are similar to humans (Plous, 1993; Gunnthorsdottir, 2001; Tisdell et al., 2006). Reynolds and Braithwaite (2001) identify the conservation status of species (rare and endangered) as having unique characteristics because they are considered the two most important factors affecting the visitor experience.
Similarly, Cárdenas and Lew (2016) also found that respondents more concerned about the species at risk are more likely to make a conservation donation. Nevertheless, their findings also indicate that for some species, the WTD were not influenced by the respondents' attitudes towards protecting the species. As well, various variables influence an individual's willingness to spend money, including age and gender (Birney and Heinrich, 1991), occupation, educational background and income level (Hun and Anuar, 2014).

Di Minin et al. (2013) found an association between the social and economic characteristics of visitors having preferences for some species and being guided by the characteristics of these species. They found that visitors with higher incomes tended to be more interested in a large, charismatic and popular wildlife (megafauna). In contrast, low-income visitors tended to select a broader range of species. Charisma is a common feature used to describe flagship species (Lorimer 2007). In contrast, Albert et al. (2018) discovered that social characteristics do not determine preferences for specific species. Similar results were obtained by Cárdenas and Lew (2016) indicating that gender and age do not influence the likelihood of donating to protect species at risk.

Nevertheless, Albert et al. (2018) see that preferences are shown for species that are regarded as large mammals. The study also revealed that all visitor segments were generally attracted to Felidae (which is classified as a large cat) and elephants. Studies suggest 
that wildlife species with certain charisma can affect a person's willingness to pay (WTP) for their conservation. Duffield et al. (2006) state that, in Yellowstone National Park, charismatic animals tend to be at the top of the list of animals to visit, including grizzly bears, wolves and large deers. In the same line, MacMillan et al. (2002) in their study, mentioned that superior and charismatic species produced higher WTP.

Indonesia is known as a country with an amazing and rich fauna that attracts the attention and admiration of people worldwide. Among ASEAN countries, Indonesia has a National Biodiversity Index that reaches 1, making Indonesia the country with the highest biodiversity in Southeast Asia (von Rintelen et al., 2017). Unfortunately, a large number of them are listed in the Minister of Environment and Forestry Regulation (Permen LHK) No. P.106/ /MENLHK/SETJEN/KUM.1/12/2018, as species that require protection status. As many as 787 species received the status of protected animal species. However, many of the endemic species are facing threats from illegal wildlife trades. Among them, 25 species are classified as priority species due to their threatened status (Decree of the Director General of KSDAE No. 180/IVKKH/2015), which need population growth due to their high number of illicit trade. The lack of funding impedes expanding the scope and breadth of existing conservation efforts (Ceballos et al., 2017). Accordingly, experts highlighted the essential role of charitable donations and private philanthropy in raising resources and supporting biodiversity conservation (Miller, 2014; Sachs et al., 2009). Research from Metrick and Weitzman (1996) conclude that physical features (e.g. physical length) were better predictors of government spending decisions on endangered species conservation than the science-based attributes. This suggests that the chances of survival of many species do not depend solely on biological requirements (e.g. minimum viable population) but also with respect to human preferences. (Colléony et al. 2017). Changing the way wildlife is viewed will have a major impact on wildlife protection (Sunkar et al. 2020). Lundberg et al. (2019) suggest that the factors that motivate the reasons for donating to various types of species and ecosystems vary, which justifies the importance of considering the various motivations that underlie the donation behaviour. For this reason, there are three research questions that must be addressed: (1) what are the characteristics of visitors to zoos and safari parks in Indonesia? (2) is there any preference on the part of visitors towards certain mammals? (3) do visitors' WTD influenced by his or her preference for certain species? With these in mind, this study has three objectives: (1) Identify the characteristics of visitors to Indonesia's zoos and safari parks; (2) Determine visitors' preferences for conservation of endangered mammals; and (3) Identify preference factors that determine willingness of zoos/safari parks visitors to donate.

\section{RESEARCH METHOD}

There are 12 priority mammal species in this study, which are amongst the most traded species found during wildlife operation, according to the Indonesian Director General of Law Enforcement, Ministry of Environment and Forestry (Dir. PPH 2020a, 2020b). The 12 species comprised of seven non-primate mammals - Sumatran elephant (Elephas maximus sumatranus), Sumatran tiger (Panthera tigris sumatrae), Sumatran rhinoceros (Dicerorhinus sp.), Sun bear (Helarctos malayanus), Anoa (Bubalus sp.), Deer (Rusa sp.), and Sunda pangolin (Manis javanica) and 5 primate species Orangutan (Pongo sp.), Yaki (Macaca nigra), Siamang (Symphalangus syndactylus), Javan gibbon (Hylobates moloch), and Slow loris (Nycticebus sp.). The nonprimate mammals included in this priority wildlife classification are large mammals, the smallest of which is a Sunda pangolin. Adult Sunda pangolins may weigh as much as $12 \mathrm{~kg}$. The International Biological Program limits large mammals as mammals with an adult body weight greater than five kilograms (Suyanto and Semiadi, 2004).

Data were collected between January - February 2020 at four zoos and three safari parks in four (4) provinces in Indonesia, namely DKI Jakarta (Ragunan Wildlife Park), West Java (Bandung Zoo, Lembang Zoo, Cisarua Safari Park), East Java (Jatim Park 2/Batu Secret Zoo and Prigen Safari Park), and Bali (Bali Safari Park). Information were gathered through questionnaires, of which the validity and reliability tests were administered in January 2020 to 110 visitors of Ragunan Wildlife Park and those who have visited zoos/safari parks, live in Bogor and citizens of Indonesia. Pre-survey accounted for $10 \%$ or more of the total respondents.

Following the preliminary survey, a survey was undertaken, which involve about 1,011 visitors (respondents). The sampling unit was the household, which means that only a family representative can participate in the survey. Furthermore, only 18 years of age or older were interviewed, on the basis that 18 is the minimum age for marriage under the Indonesian law (add the regulation); 18 is also the average age at which an individual completes secondary school and can therefore be considered an adult who may be responsible for their affairs. Adult respondents can be categorized into young adult (18-35 years), middle-aged adult (36-55 years) and older adult (over 55 years). Accidental (convenience) sampling was performed. This technique was chosen because it was possible to obtain a specific sample, and it was simple to apply. Interviews were conducted on-site. For zoos, interviews were allowed in the zoo area, while interviews were more restrictive for Safari parks. Interviews could only be conducted in car parks before entering the Safari Park, except for Prigen Safari Park, where interviews could be held in Safari Park. 
The questionnaire was delivered to respondents on an individual basis to minimize non-response. The survey begins with a general characteristic of the respondents and the nature of their visits. The next step is to put in place the hypothetical market of WTD. Visitors have the option of being able to write their answers to reduce interviewer bias (Tourangeau et al., 2007) or the interviewer can be asked to write them down. Some respondents, especially elderly visitors and those caring for children or toddlers, ask interviewers to read questions and fill answers on their behalf. The interviewer always approves this request, and sometimes, it is important to ensure that the respondent understands the question and their answers are recorded correctly.

A photographic questionnaire technique was used to assess visitors' psychological preferences for the species. A picture of each species was provided to the respondents. Respondents evaluated their preferences for the pictures. When people saw photographs, the information in the picture was not the only factor that affected their attitude since the images provided memories of past experiences and prior knowledge (Williams and Cary, 2002, Kaplan and Kaplan, 1989).

\section{RESULT AND DISCUSSION}

Overall, the response rate to the questionnaire (answering all questions) was greater than 90\%, while the level of willingness to respond was greater than $70 \%$. These results are classified as very good. This is because according to Ziegler et al. (2012), a $60 \%$ rate of return is classified as sufficient while $70 \%$ is classified as very good.

\section{Demographic Characteristics of Zoos/Safari Parks Visitors}

Of all visitors to Indonesia's zoos and safari parks, nearly $100 \%$ are local persons or come from adjacent areas. All zoos are located in big cities. This means that most people also have a higher education. Dewi (2005) also found that Safari Park visitors came from Jakarta, Depok, Bogor, Tangerang and Bekasi. More specifically, in the case of non-primate mammals (Table 1 and 2), most visitors come from the category of students. This finding is supported by the Sommer (2008) study, which found that student visitors preferred large, attractive, strong and unusual/rare species.

Table 1 Respondents demographics viewing primates.

\begin{tabular}{|c|c|c|c|c|c|}
\hline Variable & DKI Jakarta (\%) & West Java (\%) & East Java (\%) & Bali (\%) & Mean (\%) \\
\hline \multicolumn{6}{|l|}{ Gender } \\
\hline Male & 40,26 & 51.00 & 58.54 & 50.00 & 49.95 \\
\hline Female & 59.74 & 49.00 & 41.46 & 50.00 & 50.05 \\
\hline \multicolumn{6}{|l|}{ Age (year) } \\
\hline $18-24$ & 35.06 & 30.00 & 39.02 & 14.30 & 30.00 \\
\hline $25-34$ & 29.87 & 32.00 & 30,15 & 35.70 & 31.93 \\
\hline $45-59$ & 18.18 & 25.00 & 0 & 14.30 & 10.83 \\
\hline \multicolumn{6}{|c|}{ Education level attain } \\
\hline High school & 48.05 & 39.00 & 70.73 & 64.30 & 55.52 \\
\hline Bachelor & 35.06 & 35.00 & 9.76 & 21.40 & 20.00 \\
\hline \multicolumn{6}{|l|}{ Occupation } \\
\hline Private & 32.47 & 38.00 & 70.73 & 42.90 & 46.02 \\
\hline Housewife & 16.88 & 13.00 & 2.44 & 21.40 & 13.43 \\
\hline Others & 28.57 & 10.00 & 17.07 & 21.40 & 19.26 \\
\hline \multicolumn{6}{|c|}{ Monthly income (million rupiahs) } \\
\hline $2,5-3,5$ & 14.29 & 52.00 & 34.15 & 14.30 & 28.68 \\
\hline$>3,5$ & 46.75 & 13.00 & 29.27 & 64.30 & 38.33 \\
\hline
\end{tabular}

Table 2 Respondents demographics viewing non-primate mammals

\begin{tabular}{|c|c|c|c|c|c|}
\hline Variable & DKI Jakarta (\%) & West Java (\%) & East Java (\%) & Bali (\%) & Mean (\%) \\
\hline \multicolumn{6}{|l|}{ Gender } \\
\hline Male & 36.36 & 36.00 & 58.54 & 50.00 & 45.22 \\
\hline Female & 63.64 & 52.00 & 64.10 & 58.30 & 59.51 \\
\hline \multicolumn{6}{|l|}{ Age (year) } \\
\hline $18-24$ & 41.56 & 53.00 & 28.21 & 20.80 & 35.89 \\
\hline $25-34$ & 12.99 & 17.00 & 38.46 & 25.00 & 23.36 \\
\hline $35-44$ & 25.97 & 14.00 & 17.95 & 37.50 & 23.85 \\
\hline
\end{tabular}




\begin{tabular}{|c|c|c|c|c|c|}
\hline Variable & DKI Jakarta (\%) & West Java (\%) & East Java (\%) & Bali (\%) & Mean $(\%)$ \\
\hline $45-59$ & 20.78 & 12.00 & 27.50 & 36.40 & 24.17 \\
\hline \multicolumn{6}{|c|}{ Education level attain } \\
\hline High school & 41.56 & 55.00 & 53.85 & 91.70 & 60.53 \\
\hline Bachelor & 32.47 & 26.00 & 17.95 & 4.20 & 20.15 \\
\hline \multicolumn{6}{|l|}{ Occupation } \\
\hline Private & 24.68 & 2.00 & 20.51 & 4.20 & 12.85 \\
\hline Students & 10.39 & 37.00 & 2.56 & 8.30 & 14.56 \\
\hline Housewife & 18.18 & 13.00 & 10.26 & 0 & 10.36 \\
\hline \multicolumn{6}{|c|}{ Monthly income (million rupiahs) } \\
\hline $2,5-3,5$ & 12.99 & 29.00 & 23.08 & 37.50 & 25.64 \\
\hline$>3,5$ & 54.55 & 15.00 & 33.33 & 33.30 & 34.04 \\
\hline
\end{tabular}

Data retrieval in Bali Province is very small compared to respondents from the other three provinces. This relates to licensing issued by the conservation institution that only allows data retrieval to be done in the parking lot and close to the ticket window. No data collection is possible after the ticket window. Moreover, many respondents in Bali do not want to be interviewed, which is probably because they have not entered the safari park (for those who have just arrived) or want to return home immediately (for those who have already left). Furthermore, no international visitors are interested in being interviewed. Thus, the Bali interviewees' results will be combined with the East Java results in this research.

Similar results obtained in various conservation institutions in Indonesia were also found by Dewi (2005), who obtained data that most respondents in Safari Park Indonesia were women aged between 22-35 years. In addition, it concluded that they were highly educated and had private employees' jobs. Similar to Indonesia, similar results were also obtained in other countries for those visiting the zoo in Japan by Uozumi (2010). They tend to have the same demographic characteristics; for example, more women answered (59\%), aged between 20-39 $(60 \%)$ and $65 \%$ have high school education and above. Besides that, the studies also revealed that Japanese visitors are dominated by private employees (35\%) and housewives $(26 \%)$. When compared with visitors to the zoo in South Carolina, United States, there are similarities and differences in visitors' demographic characteristics. The similarity lies in the fact that women also dominate respondents, even reaching $80 \%$. From the aspect of age, as many as $40.0 \%$ of visitors ranged from 30-39 years, followed by $24.9 \%$ aged between $40-49$, while the percentage of ages 18-29 was only $16.3 \%$. When combined, as many as $60 \%$ are in the age range of 30-49 (Joseph, 2008). Likewise, visitors to the Cincinnati Zoo (Fitzpatrick, 2017), dominated by the 1830 year age group (37\%), are occupied by $33 \%$ of visitors over 60 years.

Visitors to the Zoo in major cities in the UK are also dominated by visitors aged 30-44 years, while older age groups are found in coastal areas. In addition, younger visitors tend to be found equally in all places.
Housewives were also found to dominate visitors in zoos located in big cities. Visitors to the Zagreb Zoo in Croatia also show similar characteristics. The zoo located in the city also attracted the attention of women (64\%), with the dominant age group between 25-39 years (56\%), followed by the age range 44-64 years $(28 \%)$ (Knežević et al., 2016). The African region, represented by zoo visitors in Nigeria, gave the same results, namely female-dominated visitors $(50.4 \%)$ with the largest age group between 15-24 years (37.9\%), followed by age group 25-54 (37.1\%) and the majority (43.4\%) have a higher education background (Adetola and Adedire, 2018).

In contrast to other places, the research results by Hun and Anuar (2014) in Malaysia showed differences related to gender variables, where more men visited the Malaysian National Zoo. The same thing was found by Zulkarnain (2001) at the Ragunan Zoo (currently WP), where most visitors are male (65.15\%). Nevertheless, a study by Facrunnisa (2011) in Ragunan WP found that female visitors were dominated by $53 \%$. As many as $91 \%$ of visitors to the Malaysian National Zoo are dominated by the age group of 18-45 years (18-25 years of about $39 \%$ and $26-35$ of about $33.0 \%$ ) and highly educated, where about $28.8 \%$ are students (Hun and Anuar, 2014). Likewise, in the Ragunan Zoo in 2001, the majority of the visitors were from the age range of 20-29 years $(57.58 \%)$ with an average level of higher education $(48.48 \%)$ and secondary education (45.45\%) (Zulkarnain, 2001). In 2011, Ragunan WP visitors were dominated by the primary age range of 17-27 years (55\%), with secondary and tertiary education, mostly engaged in the private sector, followed by housewives and students.

In general, visitor trends in the four provinces of the study location showed similar results for the demographic variables of gender, age, educational background and occupation. First, in all provinces, more women answered the questionnaire than men (51$62.4 \%$ ), and this concludes that most of the women were visitors. Second, the age of respondents (in this case adults only) is between 18-44 years, with the most (32.1-44.0\%) in the 18-24 age range and the second majority aged $25-34$ at $19.4-31.7 \%$, followed by the age 
range 35-44 (17.7-24.0\%). Of all respondents surveyed, $47.9-54.3 \%$ were visitors with a secondary education background (high school graduates or equivalent) and $23.3-32.6 \%$ with a tertiary education background. Finally, variables with similar trends in all provinces are jobs found by private employees $(\sim 26.48 \%)$, students $(\sim$ $20.5 \%)$ and housewives $(\sim 14.58 \%)$ occupying the top three positions.

It can be concluded from various comparisons of studies above, including those conducted in this study, the majority of visitors of zoos/safari parks were women. Women relate to their role as "caregiver" or "caretaker". Many communities, especially families with children, cannot see wildlife directly in their natural habitat. Therefore, the only option is wildlife attractions in locations that can be easily seen (Lück, 2007). In addition, there is a tendency for women exhibit higher pro-environment attitudes than men (Zelezny et al., 2000). Brandtzaeg (2017), in his research related to Facebook, also found that women were more inclined to support environmental issues, including donating for the benefit of the environment.

Similarly, Woods (2000) observed that women preferred wildlife that could be touched, fed and approached. Kellert (1989) also noted that women tend to be oriented towards wildlife that provides affection, closeness and empathy. Animals found at the zoo and safari park meet these conditions.

\section{Willingness to Donate}

Based on information collected from the survey returned by all respondents in 4 provinces, willingness to contribute to the species through donations (Willingness to Donate - WTD) varies by species (Table 3) and provinces (Table 4). Table 3 also indicates that respondents placed higher donation levels for nonprimate mammals (all primates are in the bottom 5). Conversely, Table 4 shows that the largest number of respondents were willing to donate more to primates $(93.17 \%)$ than non-primate $(82.44 \%)$. This suggests that a person is willing to donate a larger amount of money to non-primate mammals. The results of Table 3 are also confirmed by previous research. Lindsey et al. (2007) found that while there are important variations in visitor preferences for mammal species, large cats, elephants, and rhinoceros were the most popular species among visitors. Another study by Macjejewski and Kerley's (2014) also placed elephants among the top popular species.

The three charismatic mammals were selected as the most donated by the West Java and East Java \& Bali visitors combined. Meanwhile, for the visitors of DKI Jakarta, although primate is the first choice, the three big species of charismatic mammals also occupy the first places in the non-primate category. When people are naturally more concerned about charismatic species, they will be more willing to fund conservation programs that focus on these species (Kontoleon and Swanson, 2003). For conservation purposes, charisma can be used in public communication (Veríssimo et al., 2017) and for fundraising/donations for the species. Likewise, Colléony et al. (2017) noted that the state of conservation of species (threatened with extinction) has not determined the value of the willingness to pay (WTP), but that the value of the WTP was more determined by the charismatic value of the species. In contrast, earlier findings by Caro and O'Doherty (1999) highlight that the interest in large mammals made visitors aware of the value of the rarity of a species, which caused them to pay more to see it voluntarily.

Table 3 Average amount of donation that community willing to give

\begin{tabular}{|c|c|c|}
\hline No. & Species & WTD (IDR) \\
\hline 1. & Sumatran elephant (Elephas maximus sumatranus) & $27,129,923.00$ \\
\hline 2. & Sumatran tiger (Panthera tigris sumatrae) & $23,468,177.17$ \\
\hline 3. & Sumatran rhinoceros (Dicerorhinus sp.) & $21.590 .744,33$ \\
\hline 4. & Sun bear (Helarctos malayanus) & $13,108,097.33$ \\
\hline 5. & Anoa (Bubalus sp.) & $5,747,282.17$ \\
\hline 6. & Deer (Rusa sp.) & $5,018,335.50$ \\
\hline 7. & Sunda pangolin (Manis javanica) & $2,856,949.50$ \\
\hline 8. & Orangutan (Pongo sp.) & $1.771 .817,33$ \\
\hline 9. & Yaki (Macaca nigra) & $1.628 .387,67$ \\
\hline 10. & Siamang (Symphalangus syndactylus) & $1,602,048.83$ \\
\hline 11. & Javan gibbon (Hylobates moloch) & $1,453,518.50$ \\
\hline 12. & Slow loris (Nycticebus sp.) & $1,380,276.17$ \\
\hline
\end{tabular}


Table 4 'Visitors' average willingness to donate by province.

\begin{tabular}{|c|c|c|c|c|c|c|}
\hline \multirow{2}{*}{ No. } & \multicolumn{2}{|c|}{ DKI Jakarta } & \multicolumn{2}{|c|}{ West Java } & \multicolumn{2}{|c|}{ East Java + Bali } \\
\hline & Species & IDR & Species & IDR & Species & IDR \\
\hline 1. & Yaki & $3,086,170.00$ & Rhinoceros & $6,465,370.50$ & Elephant & $73,047,619.00$ \\
\hline 2. & Orangutan & $2,875,000.00$ & Elephant & $6,017,622.00$ & Tiger & $66,338,235.50$ \\
\hline 3. & Siamang & $2,589,130.00$ & Tiger & $2,232,575.50$ & Rhinoceros & $56,755,882.00$ \\
\hline 4. & Slow loris & $2,528,723.00$ & Anoa & $1,822,214.00$ & Sun bear & $37,290,000.00$ \\
\hline 5. & Elephant & $2,324,528.50$ & Sun bear & $1,130,882.50$ & Anoa & $14,905,882.50$ \\
\hline 6. & Javan gibbon & $2,189,255.00$ & Orangutan & $1,126,166.50$ & Deer & $13,938,889.00$ \\
\hline 7. & Tiger & $1,833,721.00$ & Javan gibbon & $937,118.50$ & Sunda pangolin & $7,526,315.50$ \\
\hline 8. & Rhinoceros & $1,550,980.50$ & Yaki & $923,993.00$ & Siamang & $1,400,300.00$ \\
\hline 9. & Sun bear & $903,409.50$ & Slow loris & $857,105.50$ & Orangutan & $1,314,285.50$ \\
\hline 10. & Deer & $517,441.00$ & Siamang & $816,716.50$ & Javan gibbon & $1,234,182.00$ \\
\hline 11. & Anoa & $513,750.00$ & Sunda pangolin & $641,901.50$ & Yaki & $875,000.00$ \\
\hline 12. & Sunda pangolin & $402,631.50$ & Deer & $598,676.50$ & Slow loris & $755,000.00$ \\
\hline
\end{tabular}

Based on the results in Table 4, visitors in DKI Jakarta Province prefer to pay higher for the conservation of primates. In contrast, the trend in West Java and East Java provinces is that visitors are willing to pay more for non-primates. The interviewees at DKI Jakarta were at Ragunan WP, which has a Schmutzer primate centre within the WP and is located near the main entrance of the visitors. Schmutzer has various programs related to primate conservation education, which improves visitors' understanding of primates. In their study of primates, Abd Mutalib et al. (2017) also concluded that media play a significant role in the perception of primates among visitors. Wilson and Tisdell (2004) also draw the same conclusion, that once visitors have received more information about a species and its state of conservation, they will therefore have a strong interest in supporting these threatened species. In addition, DKI Jakarta's visitors are female-dominated $(59.74 \%)$ and Abd Mutalib et al. (2017) state that statistically, females were found to have more knowledge of primates than males. They also found that respondents aged 20 to 29 were the best informed about primates compared to other age groups. These findings support data acquisition in this study, according to which DKI Jakarta respondents are predominantly women aged 18 to 24 , followed by 24 to 34.

In contrast to the province of DKI Jakarta with no safari park, visitors from the provinces of West Java, East Java and Bali were also interviewed in the Safari Park, located in all three provinces. Safari Park Indonesia allows visitors to interact with the animals outside the cage. Additionally, Safari Park also provides visitors with the opportunity to view various wildlife attractions, most of them showcasing large bodied wildlife, such as Jatim Park 2 in East Java Province. One of the determinants of tourist visits to a location is what will be found or seen in that place. This was also observed by Di Minin et al. (2012), who conclude that location marketing increases 'visitors' expectations. In addition, showcasing animals would also enhance visitors understanding of large mammals and reduce the risk of being frightened by the animal because visitors are shown the positive sides of the wildlife. This was also underlined by Godinez and Fernandez (2019) that interactions with zoo animals can influenced and changed visitor perception.

Consequently, visitors in East Java and Bali combined, have better knowledge of large wildlife species and tends to make higher donations to these species. This is aligned with the knowledge enhancement of the visitors on primates found in Ragunan WP as discussed above. Supporting the findings of this research, were the study results of Tisdell et al. (2007) and Wilson and Tisdell (2004) who also found their knowledge of the species influences that visitor preferences.

A further interesting results obtained from Table 5 , was that, overall, non-primate ranks first in terms of the number of donations received. However, this result is inversely proportional to the number of people willing to make donations to non-primates (Table 5). Table 5 is related to the number of respondents willing to donate, unwilling to donate, and those who were unsure whether to donate to certain species. Related to the later, an insignificant number of respondents were doubtful, totaling $0.92 \%$ for non-primate and $0.8 \%$ for primates. The high percentage of respondents willing to donate for species conservation indicated that society cares about the survival of the species. This could also imply that zoos/safari parks are indeed great places to boost ' 'someone's empathy toward wildlife. 
The species that received the least amount of donations (from the number of donors - Table 5) are often judged to not having human-friendly or unknown attributes, such as the colour black (anoa and sun bears for non-primate mammals; yaki for a primate), and nocturnal with large eyes (slow loris), which are often associated with ghosts. It can be concluded that the community will tend to make donations to species that do not give fear/negative feelings and are easily recognizable. Indeed, specific features, such as physical appearance, body size, achromatic components including surface pattern, texture and colour (skin/fur), taxonomic classification and similarity with humans, etc., will determine whether wildlife will be liked or ignored (Rádlová et al., 2018). The preference toward largebodied mammal have been explained previously.

\section{3. 'Visitors' psychological preferences for mammal conservation}

The preference for certain species can also determine willingness to donate. Table 5 above shows that out of all the species studied in this research, the Sunda pangolin (Manis javanica) attained the highest number of people willing to donate, the smallest number of people unwilling to donate, and also the smallest number of questionable decisions. This demonstrates that the majority of the society are informed about the Sunda pangolin. This is made possible because Sunda pangolin is one of the most heavily traded animals and often shown and discussed in mass media. Moreover, it can be seen from Table 6; society places mammals as species that are native species of Indonesia and serves as the main reason for their willingness to donate; the society regard Sunda Pangolin as a beautiful species hence require protection. There are three secondary attributes attached to the 12 wildlife studied and classified under conservation status (rare/endemic) and physical appearances (beautiful/cute/frightening).

Table 5 Percentage of WTD for conservation of mammals.

\begin{tabular}{|c|c|c|c|c|c|}
\hline \multirow{2}{*}{ No. } & \multirow{2}{*}{ Species } & \multirow{2}{*}{$\begin{array}{l}\text { Classifi- } \\
\text { cation* }\end{array}$} & \multicolumn{3}{|c|}{ Willingness to Donate (\%) } \\
\hline & & & Willing & Unwilling & Don't know \\
\hline 1 & Sunda pangolin (Manis javanica) & $\mathrm{M}$ & 83.51 & 16.13 & 0.36 \\
\hline 2 & Tiger (Panthera tigris sumatrae) & $\mathrm{M}$ & 82.80 & 16.13 & 1.08 \\
\hline 3 & Rhinoceros (Dicerorhinus sumatrensis) & $\mathrm{M}$ & 82.44 & 16.49 & 1.08 \\
\hline 4 & Elephant (Elephas maximus sumatranus) & $\mathrm{M}$ & 82.08 & 16.85 & 1.08 \\
\hline 5 & Deer (Rusa sp.) & $\mathrm{M}$ & 82.08 & 16.85 & 1.08 \\
\hline 6 & Anoa (Bubalus sp.) & $\mathrm{M}$ & 82.08 & 16.85 & 1.08 \\
\hline 7 & Sun bear (Helarctos malayanus) & $\mathrm{M}$ & 82.08 & 17.20 & 0.72 \\
\hline \multicolumn{3}{|c|}{ Average } & 82.44 & 16.64 & 0.92 \\
\hline 8 & Orangutan (Pongo sp.) & $\mathrm{P}$ & 93.98 & 5.22 & 0,8 \\
\hline 9 & Javan gibbon (Hylobates moloch) & $\mathrm{P}$ & 93.17 & 6.02 & 0,8 \\
\hline 10 & Siamang (Symphalangus syndactylus) & $\mathrm{P}$ & 93.17 & 6.02 & 0,8 \\
\hline 11 & Yaki (Macaca nigra) & $\mathrm{P}$ & 92.77 & 6.43 & 0,8 \\
\hline 12 & Slow loris (Nycticebus sp.) & $\mathrm{P}$ & 92.77 & 6.43 & 0.8 \\
\hline \multicolumn{3}{|c|}{ Average } & 93.17 & 6.02 & 0.8 \\
\hline
\end{tabular}

Note: $*=\mathrm{M}$ (non-primate mammals); $\mathrm{P}$ (primate)

Table 6 Attributes affecting the preference for willingness to donate.

\begin{tabular}{|l|l|c|c|c|c|}
\hline \multirow{2}{*}{ No. } & \multicolumn{2}{|c|}{ Species } & \multicolumn{4}{c|}{ Willingness to Donate } \\
\cline { 3 - 6 } & & Main reason & Percentage (\%) & Other reason & Percentage (\%) \\
\hline 1. & Sumatran elephant & Endemic & 43.67 & Cute & 25.00 \\
\hline 2. & Sumatran tiger & Endemic & 34.05 & Beautiful & 30.27 \\
\hline 3. & Sumatran rhinoceros & Endemic & 48.25 & Beautiful/frightening & 17.78 \\
\hline 4. & Sun bear & Endemic & 32.31 & Beautiful & 22.15 \\
\hline 5. & Anoa & Endemic & 62.26 & Frightening & 10.51 \\
\hline 6. & Deer & Endemic & 39.48 & Beautiful & 35.60 \\
\hline 7. & Sunda pangolin & Beautiful & 34.62 & Endemic & 33.97 \\
\hline 8. & Orangutan & Endemic & 35.98 & Beautiful & 17.88 \\
\hline 9. & Yaki & Endemic & 33.64 & Rare & 19.58 \\
\hline 10. & Siamang & Endemic & 35.41 & Rare & 18.90 \\
\hline 11. & Javan gibbon & Endemic & 35.08 & Beautiful & 22.78 \\
\hline 12. & Slow loris & Endemic & 29.30 & Cute & 21.44 \\
\hline
\end{tabular}


Albert et al. (2018), in their research, concluded that large mammals are charismatic species because they are considered as beautiful, impressive, or endangered species, and they classify charismatic species based on: physical appearance (beautiful and cute) and their nature towards humans (dangerous and impressive) and conservation status (rare and endangered). Priority choice of species given donations is more patterned based on the choice of visitors. Visitors represent the general public from various types of work and a variety of knowledge possessed about wildlife (in which case the amount of donations) is more influenced by each individual's perception. According to the result in Table 6 and charismatic classification by Albert et al. (2018), charismatic species can be frightening - not always beautiful or cute. As can be seen in Table 6, frightening is mostly not found together with beautifulfor the same species, except for the Sumatran rhino (Table 6), in which rhinoceros is categorized as beautiful but also frightening. The dichotomy may create a form of doubt. Janovcová et al. (2019) found such dichotomy often found with reptiles.

Especially for the primate, the attribute of the species with a null value, is frightening. Rádlová et al. (2018), in his research related to primate facial expressions favoured by humans, divides primates into three groups based on the degree of similarity with humans: (1) Prosimian, small groups of primates such as lemurs and lorises are regarded as least similar to those of humans.; (2) Platyrrhini, a group of new-world monkeys such as marmosets and other monkeys from the Americas; (3) Catarrhini, a group of old-world monkeys such as gibbons, gorillas and orangutans are considered

\section{CONCLUSION}

The majority of adult category visitors to zoos and safari parks in all provinces (DKI Jakarta, West Java, East Java, Bali) were women (51-62.4\%) aged 18-44 years, with most categories as young adult 18-24 (32.1$44.0 \%$ ); having a secondary education background (high school graduate or equivalent) $47.9-54.3 \%$ and $23.3-$ $32.6 \%$ tertiary education; private sector employee dominance $(\sim 26.48 \%)$ with the top three jobs in each province being private employees, students and housewives.

Respondents' preferences for the 12 species studied varied and are influenced by various variables such as species popularity, which was driven by species publicity in the media, physical attractiveness, size, and conservation status. Mammals, mega-herbivores and large carnivores are very popular among young adult visitors.

Their preferences influence visitor determination of the amount of willingness to donate for species conservation on certain wildlife affected by various demographic variables. Overall, visitors placed the most similar to humans. The five primate species in this study fall into the Catarrhini category. The inner part of the face is one of the most powerful factors for determining the beauty of Catarrhini primate species in terms of eye size, interocular length, mouth width, and length from nose to mouth (or eye to mouth). Furthermore, people prefer furry primates, such as indicated by beautiful shown for orangutan and Javan gibbon. Siamang is also a species covered with fur, however, the fur colour is black, which is less preferred.

From the discussion above, it can be concluded that mega-herbivorous species and large carnivores are very popular wildlife among young adult visitors. At the same time, older people tend to choose to see wildlife species that are not easily seen (Lindsey et al., 2007). Referring to Table 1 , the age of most visitors in this study is between $18-44(84.8 \%)$ and are dominated by ages $18-$ $34(65 \%)$ (young visitor category). This is because the physical abilities of elders have been reduced. Wildlife that is more difficult to observe directly are generally displayed in cages.

This study confirmed that wildlife with larger body sizes get added value compared to smaller body sizes, which is caused by the ease of viewing. The greatest diversity of mammals is the most significant feature for visitors to a protected area, followed by large predators (Lindsey et al., 2007). The results above confirm that community valuations are based on species preferences in determining donations or conservation prices. Macjejewski and Kerley (2014) also conclude that species type is not the only factor influencing visitor preferences for large mammals.

rhinoceros, elephant and tigers as the three priority species to be conserved in terms of the amount of donations for conservation provided. It is clear that, from the people's perspective, these three charismatic species have a very high conservation value.

\section{REFERENCES}

[Dir PPH] Direktorat Pencegahan dan Pengamanan Hutan. 2020a. Buku Panduan Penanganan (Handling) Satwa Mamalia. Jakarta: Direktorat Pencegahan dan Pengamana Hutan, Direktorat Jenderal Penegakan Hukum, Kementerian Lingkungan Hidup dan Kehutanan.

[Dir PPH] Direktorat Pencegahan dan Pengamanan Hutan. 2020b. Buku Panduan Penanganan (Handling) Satwa Primata. Jakarta: Direktorat Pencegahan dan Pengamana Hutan, Direktorat Jenderal Penegakan Hukum, Kementerian Lingkungan Hidup dan Kehutanan.

Abd Mutalib AHBA, Kamaruszaman SAB, Zainol MZB, Rameli NIAB dan Rosely NFN. 2017. A brief study on ' 'public's perception, knowledge and willingness 
to participate in primate conservation. Malayan Nature Journal. 69(4):369-381.

Adetola B O, Adedire O P (2018). 'Visitors' motivation and willingness to pay for conservation in selected zoos in Southwest Nigeria. J Appl Sci Environ Manage. 22(4):531-537.

Albert C. Luque GM dan Courchamp F. 2018. The twenty most charismatic species. PloS one.13(7): 0199149.

Birney BA dan Heinrich C. 1991. Understanding demographic data on zoo visitors. Journal of Museum Education. 16(2):19-22.

Brandtzaeg PB. 2017. Facebook is no Great equalizer: A big data approach to gender differences in civic 13 engagement across countries. Soc Sci Comput Rev. 35(1):103-125.

Cárdenas SA and Lew DK. 2016. Factors influencing willingness to donate to marine endangered species recovery in the Galapagos National Park, Ecuador. Frontiers in Marine Science. 3:60.

Caro, T.M. \& O'Doherty, G. 1999. On the use of surrogate species in conservation biology. Conservation Biology. 13:805-814.

Ceballos G, Ehrlich PR and Dirzo R. 2017. Biological annihilation via the ongoing sixth mass extinction signaled by vertebrate population losses and declines. Proceedings of the national academy of sciences. 114(30): E6089-E6096.

Colléony A, Clayton S, Couvet D, Saint JM, dan Prévot AC. 2017. Human preferences for species conservation: Animal charisma trumps endangered status. Biological Conservation. 206:263-269.

Dewi RK. 2005. Fungsi permintaan Taman Safari Indonesia (TSI) dengan metode biaya perjalanan. Skripsi pada Departemen Sosial Ekonomi Peternakan, Fakultas Peternakan Institut Pertanian Bogor. Unpublished.

Di Minin E, Fraser I, Slotow R dan MacMillan DC. 2013. Understanding heterogeneous preference of tourists for big game species: implications for conservation and management. Animal Conservation. 16(3):249-258.

Duffield J, Patterson D and Neher, CJ. 2006. Wolves and people in Yellowstone: Impacts on the regional economy. Download from https://Duffield, J., Patterson, D. and Neher, C.J., 2006. Wolves and people in Yellowstone: Impacts on the regional economy.defenders.org/sites/default/files/publications /wolves_and_people_in_yellowstone.pdf.

Fachrunnisa. 2011. Analisis faktor-faktor yang mempengaruhi kunjungan dan optimasi harga tiket Taman Margasatwa Ragunan Jakarta. Undergraduate thesis, Departmen of Resources and Environment, Faculty of Economy and management. IPB University. Unpublished.

Fitzpatrick M. 2017. Why do adults visit zoos? Do they want to learn or have fun? www. izea. Net: 60 .
Godinez AM and Fernandez EJ. 2019. What is the zoo experience? How zoos impact a ' 'visitor's behaviors, perceptions, and conservation efforts. Frontiers in Psychology. 10: 1746.

Gunnthorsdottir A. 2001. Physical attractiveness of an animal species as a decision factor for its preservation. Anthrozoös, 14: 204-215.

Hun S D, Anuar A. 2014. Willingness To Pay For Public Ecotourism Services in Malaysia. Center for Studies of Urban and Regional Real Estate. 32-45.

Janovcová, M., Rádlová, S., Polák, J., Sedláčková, K., Peléšková, Š., Žampachová, B., Frynta, D. and Landová, E., 2019. Human attitude toward reptiles: A relationship between fear, disgust, and aesthetic preferences. Animals. 9(5): 238.

Joseph S. 2008. From visit to action: how zoo visitor characteristics influence environmentally-responsible behavior. Tesis: Clemson University. Unpubliehed.

Kaplan R and Kaplan S. 1989. The experience of nature: A psychological perspective. Cambridge university press.

Kellert SR. 1989. Perceptions of animals in America. Perceptions of animals in American culture:5-24.

Knežević M, Žučko I and Ljuština M. 2016. Who is visiting the Zagreb Zoo: Visitors' characteristics and motivation. Sociologija i prostor: časopis za istraživanje prostornoga i sociokulturnog razvoja. 54(2 (205)169-184.

Kontoleon A and Swanson T. 2003. The willingness to pay for property rights for the Giant Panda: Can a charismatic species be an instrument for nature conservation?. Land Economics. 79: 483-499.

Lindsey, P.A., Alexander, R., Mills, M.G.L., Romañach, S. and Woodroffe, R., 2007. Wildlife viewing preferences of visitors to protected areas in South Africa: implications for the role of ecotourism in conservation. Journal of Ecotourism. 6(1): 19-33.

Lorimer, J., 2007. Nonhuman charisma. Environment and Planning D: Society and Space.25(5):911-932.

Lück, M. 2007. Captive marine wildlife: Benefits and costs of aquaria and marine parks. Marine wildlife and tourism management: Insights from the natural and social sciences: pp.130-41..

Lundberg P, Vainio A, MacMillan DC, Smith RJ, Verissimo D and Arponen A. 2019. The effect of knowledge, species aesthetic appeal, familiarity and conservation need on willingness to donate. Animal Conservation. 22(5): 432-443.

Maciejewski K and Kerley GI. 2014. Understanding 'tourists' preference for mammal species in private protected areas: is there a case for extralimital species for ecotourism? PLoS One. 9(2).

MacMillan DC, Phillip L, Hanley N and Alvarez-Farizo B. 2002. Valuing the nonmarket benefits of wild goose conservation: a comparison of interview and 
group-based approaches. Ecological Economics. 43: 49-59.

Metrick A and Weitzman ML. 1996. Patterns of behavior in endangered species preservation. Land Economics1-16.

Miller DC. 2014. Explaining global patterns of international aid for linked biodiversity conservation and development. World Development, 59:341-359.

Plous S. 1993) Psychological mechanisms in the human use of animals. Journal of Social Issues. 49: 11-52.

Rádlová, S., Landová, E. and Frynta, D., 2018. Judging others by your own standards: attractiveness of primate faces as seen by human respondents. Frontiers in psychology. 9: 2439.

Reynolds P and Braithwaite D. 2001. Towards a conceptual framework for wildlife tourism. Tourism Manage. 22: 31-42.

Sachs JD, Baillie JE, Sutherland WJ, Armsworth PR, Ash N, Beddington J, Blackburn TM, Collen B, Gardiner B, Gaston KJ, and Godfray, HCJ. 2009. Biodiversity conservation and the millennium development goals. Science.325(5947):1502-1503.

Setiawan, G.F. and Guntoro, B. 2018. Persepsi pengunjung terhadap Kebun Binatang Gembira Loka sebagai daya tarik wisata. Jurnal Kebijakan Pembangunan Peternakan, 1(1): 64-73.

Sommer R. 2008. Semantic profiles of zoos and their animals. Anthrozoös21(3): 237-244.

Sunkar A, Kusrini MD and Ramadhani FS. 2020. Role of culture in the emotional response towards komodo dragon in Komodo and Rinca Islands of Komodo National Park. In BIO Web of Conferences.Vol(19): 00021). EDP Sciences.

Suyanto A and Semiadi G. 2004. Keragaman mamalia di sekitar daerah penyangga Taman Nasional Gunung Halimun, Kecamatan Cipanas, Kabupaten Lebak. Berita Biologi 7(1): 87-94.

Tisdell C, Nanth HS, Wilson C. 2007. Endangerment and likeability of wildlife species: how important are they for payments proposed for conservation? Ecological Economics, 60:627-633.

Tisdell C., Wilson C., Swarna Nantha H. 2006. Public choice of species for the 'Ark': phylogenetic similarity and preferred wildlife species for survival. Journal of Nature Conservation. 14:97-105.

Tourangeau R, Rips LJ, dan Rasinski K. 2007. The psychology of survey response. New York, NY: Cambridge University Press.

Uozumi A. 2010. Do zoos work at raising awareness? Dissertation: Imperial College London. Unpublished.

Veríssimo D, Vaughan G, Ridout M, Waterman C, MacMillan D and Smith RJ. 2017. Increased conservation marketing effort has major fundraising benefits for even the least popular species. Biological Conservation. 211: 95-101.

Von Rintelen K, Arida E and Häuser C. 2017. A review of biodiversity-related issues and challenges in megadiverse Indonesia and other Southeast Asian countries. Research Ideas and Outcomes. 3:20860.

Williams KJ and Cary J. 2002. Landscape preferences, ecological quality, and biodiversity protection. Environment and Behavior. 34(2): 257-274.

Wilson C and Tisdell C. 2004. Knowledge of birds and willingness to pay for their conservation: an Australian case study. Economics, Ecology and the Environment. 96 (1): 1-29.

Woods B. 2000. Beauty and the beast: preferences for animals in Australia. Journal of Tourism Study.11: 25-35.

Zelezny LC, Chua PP, and Aldrich C. 2000. Elaborating on gender differences in environmentalism. Journal of Social Issues. 56: 443-457.

Ziegler J, Dearden P, and Rollins R. 2012. But are tourists satisfied? Importance performance analysis of the whale shark tourism industry on Isla Holbox, Mexico. Tourism Management. 33(3): 692-701. DOI: 10.1016/j.tourman. 2011.08.004.

Zulkarnain. 2001. Studi karakteristik pengunjung dan pendugaan permintaan rekreasi terhadap Kebun Binatang Ragunan Jakarta Selatan. [Undergraduate thesis]. Faculty of Agriculture, IPB University. Unpublished. 